\title{
Большой академический кинотеатр СССР на площади Свердлова: новые материалы к истории проведения конкурса 1936 года
}

\author{
Ю.Д.Старостенко, НИИТИАГ, Москва
}

В статье на основании вновь выявленных архивных документов и публикаций в специализированных периодических изданиях 1930-х годов детально воссоздается история проведения конкурса 1936 года на проект Большого академического кинотеатра СССР на площади Свердлова (ныне Театральная площадь) в Москве, которая до настоящего времени оставалась практически неизвестной. Совокупность найденныхуникальных материалов позволила выяснить, когда именно возникла идея проектирования грандиозного кинотеатра в самом центре Москвы, и проследить, как протекал процесс разработки конкурсных проектов. Они также позволили установить, что, несмотря на весьма жесткую критику конкурсных работ, проект А.Н. Душкина и его соавторов стал основой для дальнейшего проектирования здания кинотеатра. Найденное задание на проектирование Большого академического кинотеатра позволило установить, что многие претензии критиков к конкурсным проектам были фактически предопределены требованиями, закрепленными в этом задании. Ориентированное на европейский и американский опыт строительства роскошных зданий кинотеатров и исходившее из той роли, которую должно играть будущее здание после реконструкции Москвы, проектное задание диктовало создание чрезмерно большого для своей функции здания. Кроме того, рассмотрение конкурса в контексте разработки проекта реконструкции столицы и с учетом ключевых задач, которые ставились перед советскими архитекторами, дало возможность объяснить расширение числа участников конкурсного проектирования и причины, по которым единственным напоминанием об этом конкурсе в пространстве Москвы остался вестибюль станций метро «Площадь Революции» и «Театральная» ${ }^{1}$.

Ключевые слова: кинотеатр, архитектурный конкурс, реконструкция Москвы, советская архитектура, 1930-е.

The Great Academic Cinema of the USSR on Sverdlov Square: New Materials on the History of the Competition in 1936

Yu.D.Starostenko, NIITIAG, Moscow

The article, based on newly identified archival documents and publications in specialized periodicals of the 1930s, recreates in details the history of the competition for the project of the Great Academic Cinema of the USSR on Sverdlov Square (now Theater Square) in in Moscow (1936). Until now, the history of this competition has remained actually unknown. Found collection of unique materials made it possible to find out exactly when the idea of designing a grandiose cinema in the center of Moscow arose, and to trace the process of developing competitive projects. They also allowed us to establish that, despite the very harsh criticism of the competition works, the project of A. N. Dushkin and his co-authors became the basis for further design of the cinema building. The found task for the design of a Great Academic Cinema allowed us to establish that many of the critics' claims to the competition projects were actually predetermined by the requirements set out in this task. Based on the European and American experience in the construction of luxury cinema theater buildings and based on the role that the future building should play after the reconstruction of Moscow, the design task dictated the creation of an excessively large building for its function. In addition, the consideration of the competition in the context of the development for the reconstruction project of Moscow and the key tasks that were assigned to Soviet architects, made it possible to explain the increase in the number of participants in the competition, as well as the reasons why the lobby of the metro stations "Ploshchad Revolyutsii" and "Teatralnaya" remains the only reminder of this competition in the space of Moscow.

Keywords: cinema, architectural competition, reconstruction of Moscow, soviet architecture, 1930s

Конкурс на Большой академический кинотеатр СССР, проведённый в 1936 году, никогда не становился объектом особого исследования. Попыткой такого рода, хотя и с определёнными оговорками, обусловленными спецификой учебного процесса, можно считать дипломную работу автора настоящей статьи, выполненную в 2006 году на кафедре советской и зарубежной архитектуры Московского архитектурного института (МАРХИ) 2 . Однако назвать этот конкурс

\footnotetext{
${ }^{1}$ Исследование выполнено за счёт средств Государственной программы Российской Федерации «Развитие науки и технологий» в рамках Плана фундаментальных научных исследований Минстроя России и РААСН.

${ }^{2}$ Научный руководитель В.Л. Глазычев. Текст дипломной работы не публиковался. Трехмерные модели конкурсных проектов, подготовленные автором к защите диплома, впоследствии были размещены им на личной странице Живого журнала (Live Journal) (https://gippo-yu.livejournal.com/31372.html). В настоящее время они часто встречаются в различных публикациях в сети Интернет, как правило, без указания авторства. Использование их в качестве иллюстраций к настоящей статье призвано хотя бы отчасти исправить сложившуюся ситуацию.
} 
«забытым» - нельзя. Графические листы к проекту Д.Н. Чечулина, выполненному им в соавторстве с К.К. Орловым, и к проекту Н.А. Душкина, соавторами которого были В.С. Белявский и Н.С. Князев, часто экспонируются на выставках в Музее архитектуры и уже неоднократно публиковались в различных изданиях, хотя и без развёрнутых комментариев ${ }^{3}$. Более того, в каталог к юбилейной выставке А.Н. Душкина были включены неопубликованные фрагменты пояснительной записки к конкурсному проекту архитектора, но история проектирования Большого академического кинотеатра в этом издании также не освещалась [2, с. 126-135].

Документы, выявленные в фонде Всесоюзного комитета по делам искусств (ВКПДИ) в Российском государственном архиве литературы и искусства (РГАЛИ) и в фонде Совета народных комиссаров СССР (СНК СССР) в Государственном архиве Российской Федерации (ГАРФ), в совокупности с публикациями в различных периодических изданиях середины 1930-х годов позволяют не только восстановить историю проведения конкурса 1936 года, но и проследить дальнейшую судьбу идеи строительства кинотеатра в самом центре Москвы на площади Свердлова. Они также дают возможность рассмотреть конкурс сразу в двух контекстах: во-первых, в контексте разработки детализированного проекта реконструкции центра Москвы (1935-1936), во-вторых, в контексте дискуссии о типологии и принципах проектирования советского кинотеатра, которая лишь недавно попадала в поле зрения историков архитектуры [3].

Впервые идея строительства в Москве «Большого кинотеатра СССР была официально зафиксирована в постановлении СНК СССР № 2439 «0 расширении сети кинотеатров г. Москвы» от 15 ноября 1935 года 4 . Вероятно, проект постановления был подготовлен Главным управлением кинофотопромышленности (ГУКФ), которое было создано в 1933 году и на тот момент функционировало при СНК СССР [4, с. 456-457]. Постановление отменяло решение Моссовета о переоборудовании кинотеатра «Форум» под театр и предписывало передать ГУКФ используемые не по назначению здание кинотеатра «Колизей» и помещение кинотеатра во «втором Доме Советов» (гостиница «Метрополь»). Также ГУКФ должен был получить для организации кинотеатров здание театра бывшего Общества политкаторжан (1931-1934, арх. В.А. и А.А. Веснины) и «занимавшееся ранее "Новым Театром" помещение в Доме Правительства», то есть помещение клуба им. А.И. Рыкова, входившего в комплекс «Дома на набережной» (1927-1931, арх. Б.М. Иофан). Также постановление предлагало ГУКФу «в течение 1936-1938 гг. построить в Москве новый “Большой кинотеатр СССР" на 4000 мест», а Моссовету, по согласованию с ГУКФ, «В месячный срок отвести участок под строительство кинотеатра» ${ }^{5}$. Все проектные и подготовительные работы по новому строительству предписывалось завершить в 1936 году.

Несмотря на то, что историю появления этого документа проследить не удалось, оно, безусловно, было следствием той новой роли, которая с первой половины 1930-х годов отводилась руководством страны кинематографу - «важнейшему из искусств». Масштабные планы предусматривали развитие советской киноиндустрии путём увеличения числа и качества выпускаемых в прокат фильмов, что было невозможно без строительства новых киностудий, фабрик, выпускающих кинооборудование и киноплёнку, а также без расширения сети кинотеатров. Не случайно именно с 1934 года в стенах Всесоюзной академии архитектуры велась разработка принципов проектирования массового советского кинотеатра, а в 1935 году «по инициативе Управления кинофикации при СНК РСФСР было начато проектирование многозальных кинотеатров для строительства на территории РСФСР» [5, с. 21]. В середине ноября 1935 года вопросы проектирования типовых кинотеатров уже обсуждались в Доме архитектора на совещании с участием заведующего планово-экономического отделом Управления кинофикации Ю.И. Гордина ${ }^{6}$ [7]. Кроме того, в начале 1935 года отмечалось 15-летие советского кинематографа7, а в конце того же года - 40-летие изобретения кинематографа [8]. В этой связи идея строительства грандиозного кинотеатра в Москве, для которой за несколько месяцев до рассматриваемого постановления был утверждён грандиозный план реконструкции, обретала особый смысл.

Поэтому нет ничего удивительного в том, что практически сразу же «в доме кино под председательством начальника Государственной конторы по кинопроектированию (Госкинопроект) Е.А. Саттель ${ }^{8}$ состоялось собрание архитекторов, деятелей искусств и творческих работников кино, посвящённое постановлению СНК СССР о строительстве в Москве “Большого академического кинотеатра СССР"» [9, с. 31]. Участвовавшие в прениях архитектор И.К. Запорожец, заслуженный деятель искусств И.Э. Грабарь, заместитель начальника ГУКФ Я.Б. Дьяков ${ }^{9}$, профессор Г.М. Болтянский и др. «подчеркивали значение нового академического кинотеатра, как одного из наиболее монументальных сооружений новой Москвы». Несмотря на уже идущую работу по проектированию многозальных кинотеатров, «большинство выступавших высказалось за однозальный монументальный кинотеатр, который

\footnotetext{
${ }^{3}$ См., например: [1, с. 130-131; 2, с. 132-135].

${ }^{4}$ Постановление СНК СССР № 2439 «0 расширении сети кинотеатров г. Москвы» от 15 ноября 1935 года (ГА РФ. Р-5446. 0п. 1. Д. 109. Л. 15-16).

${ }^{5}$ Там же. Л. 16.

${ }^{6}$ Инициалы установлены по: [6, с. 39].

${ }^{7}$ Декрет о национализации кинопроизводства, с которого официально начиналась история советского кино, был принят в 1919 году [4, с. 34], однако празднование юбилея по решению Политбюро цК ВКП(б) состоялось в январе 1935 года.

${ }^{8}$ Инициалы установлены по: [6, с. 150].

${ }^{9}$ Инициалы установлены по: [6, с. 7].
} 
вобрал бы в себя все достижения западной, в особенности американской техники строительства крупных кинотеатров и вместе с тем отражал бы гигантские достижения советской кинематографии, - “важнейшего для нас искусства"» [9, с. 32]. На этом собрании было высказано «пожелание, чтобы под новое здание был предоставлен участок на пл. Свердлова с тем, чтобы академический кинотеатр явился в архитектурном отношении завершением площади» [9, с. 31].

Однако Моссовет не спешил выделить участок под строительство отдельного здания. Об этом свидетельствует опубликованная в конце 1935 года статья А.В. Щусева, посвящённая вступлению в строй первой очереди гостиницы «Москва». В ней архитектор, освещая планы по достройке здания, упоминал, что в следующую очередь строительства гостиницы планируется включить «Большой Академический кинотеатр СССР» на 4000 мест. Предполагалось, что кинотеатр «займёт первые 4 этажа 12 этажного фасада» со стороны площади Свердлова [10, с. 6], а «центральной деталью фасада 2-й очереди, выходящего на площадь... явится главный вход в кинотеатр» [11] (рис. 1, 2). Скорее всего, это решение не встретило понимания со стороны ГУКФ, но дальнейшая информация о проектировании Большого академического кинотеатра ГУКФ относится уже к весне 1936 года. Причиной

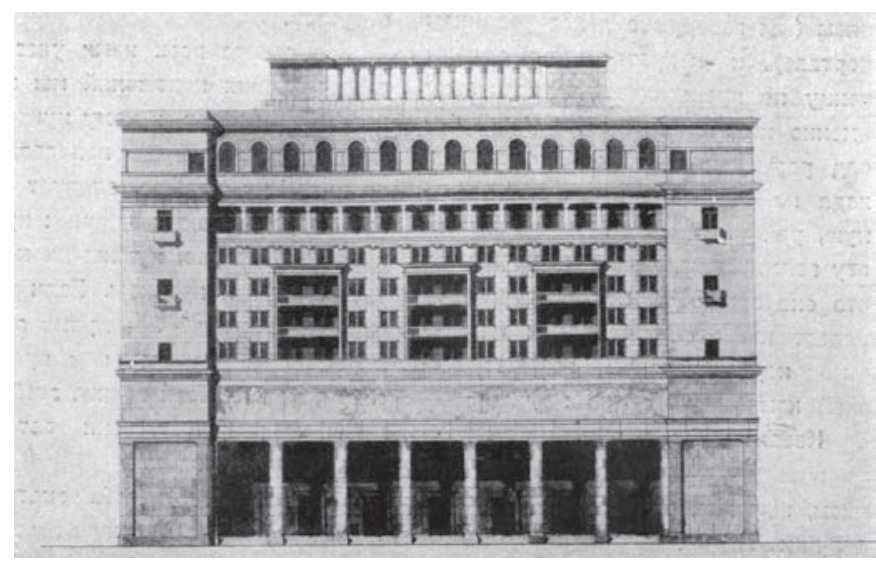

Рис. 1. Проект гостиницы «Москва». 2-я очередь строительства. Фасад со стороны площади Свердлова. Архитекторы А.В. Щусев, Л.И. Савельев, О.А. Стапран. 1935 год (источник: $[25$, c. 34])

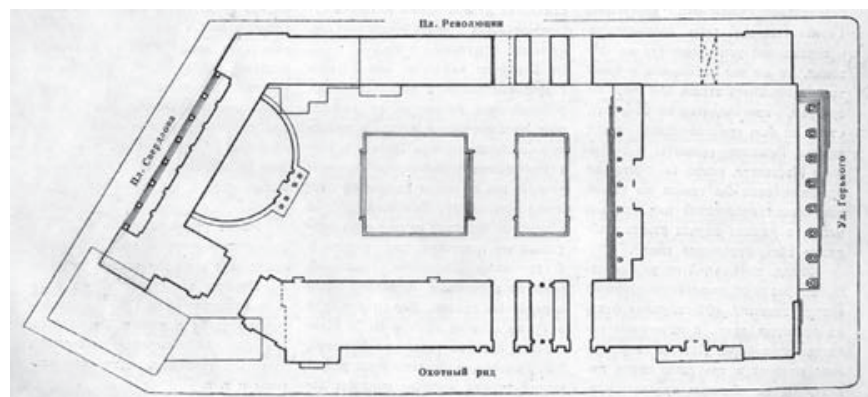

Рис. 2. Проект гостиницы «Москва». 2-я очередь строительства. Генплан. Архитекторы А.В. Щусев, Л.И. Савельев, О.А. Стапран. 1935 год (источник: [25, с. 33]) столь длительной паузы стала перестройка работы ГУКФ, которое в середине января 1936 года вошло в состав вновь организованного Всесоюзного комитета по делам искусств (ВКПДИ) при СНК СССР [4, с. 487].

Согласно протоколу «совещания замов» у председателя ВКПДИ П.М. Керженцева от 25 марта 1936 года на 31 марта было намечено обсуждение вопроса «о строительстве киногородка и Большого академического кинотеатра» ${ }^{10}$. Среди документов ВКПДИ свидетельств этого обсуждения выявить не удалось. Однако через месяц, 29 апреля 1936 года постановлением ВКПДИ «представленное ГУКФом планово-программное задание по Большому московскому академическому кинотеатру» было утверждено. Размер зрительного зала определялся в 4000 мест, вспомогательного зала для предварительных просмотров - 250 мест, объём здания намечался в 203 тысячи кубических метров ${ }^{11}$. Разработкой задания занимался, судя по всему, Госкинострой ${ }^{12}$, руководитель которого вёл заседание в Доме кино в конце 1935 года.

В этом «планово-программном задании», отложившимся в фонде ВКПДИ ${ }^{13}$, весьма подробно были прописаны требования к архитектурно-художественному оформлению здания, в котором должны были найти «широкое синтетическое применение элементы монументальной и барельефной скульптуры, монументальной живописи, фресок, натуральных камней..., металлов, ценных пород дерева, инкрустаций, специальной электроарматуры, зеркал, ковров и других мотивов и приемов классического и современного зодчества с тем, что все здание было запроектировано и оформлено в своем собственном стиле, реально отражающем назначение сооружения, как дворца кино-зрелищного искусства» ${ }^{14}$. Особое внимание уделялось «рекламному освещению», которое «должно быть обязательно архитектурно вкомпоновано в самый фасад здания и должно, само по себе, представлять высокохудо-

${ }^{10}$ Протокол № 4 совещания замов у тов. Керженцева 25/III-36 г. (РГАлИ. Ф. 962. 0п. 3. Д. 114. Л. 17).

${ }^{11}$ Постановление № 8 Всесоюзного комитета по делам искусств при СНК СССР от 29 апреля 1936 года (РГАЛИ. Ф. 962. 0п. 3. Д. 207. Л. 88).

12 Госкинопроект организован в мае 1934 года, как Проектное бюро при тресте «Киномехпром». С 1 января 1935 года был реорганизован в самостоятельную проектную контору, на правах треста, которая занималась проектированием кинофабрик, киностудий, кинотеатров и т.п. Состоял из двух отделений - Мосгоскинопроект и Ленгоскинопроект. В 1935 году им выполнялись работы по Большому кинотеатру, затраты по которым составили 8,4 тыс. руб. [Пояснительная записка к отчету «Госкинопроекта» за 1935 год (РГАЛИ. Ф. 2456. 0п. 1. Д. 162. Л. 49-60)]. Позднее переименован в Союзкинопроект.

13 В описи РГАЛИ этот документ датирован 1946 годом. Однако его орфография (например, написание слова «кино-театр»); ключевые цифры, совпадающие с текстом постановление ВКПдИ от 29 апреля 1936 года, и упоминание Отдела проектирования Моссовета, который был реорганизован в Управление проектирования в июле 1939 года, дают основание утверждать, что документ относится к 1936 году.

14 Планово-программное задание на составление проектного задания Большого академического кинотеатра СССР на 4000 человек в г. Москве. 1936 г. (РГАЛИ. Ф. 962. 0п. 17. Д. 467. Л. 3). 
жественный элемент световой архитектуры» ${ }^{15}$.

В интерьерах зрительного зала предлагалось активно использовать различные световые приемы, в том числе столь популярные в американских и европейских кинотеатрах эффекты «отражённого архитектурного освещения (из-за карнизов, в капителях колонн, светящиеся ниши и пр.)» ${ }^{16}$. Для сцены-эстрады предлагалось предусмотреть «цветовые и графические движущиеся проекции (типа «Клавилукс» Вильфреда и т.п.) ${ }^{17}$. Помимо этого, программа на проектирование, изложенная на 54 листах, охватывала довольно большое число технических аспектов - от конструкции здания и описания системы «очистка воздуха в камерах климатизации от пыли и копоти» до принципов организации фойе. Иными словами, она предусматривала проектирование здания, действительно, «вобравшего в себя все достижения западной, в особенности американской техники строительства крупных кинотеатров», как того хотели участники ноябрьского совещания в Доме кино.

Единственным моментом, который был опущен в «планово-программном задании», было точное место расположения здания кинотеатра. При этом в задании отмечалось, что «при проектировании здания кинотеатра необходимо предусмотреть удобную непосредственную связь с вестибюлем метро», а также, что «этажность здания кинотеатра и его высота определяется общей архитектурной композицией проекта в соответствии с архитектурно-планировочным заданием Отдела проектирования Моссовета и в зависимости от размеров и конфигурации участка ориентировочно допускается до 8-10 этажей нормальной высоты» ${ }^{18}$. Более того, задание предусматривало устройство фонтанов на площади перед кинотеатром, «каковые должны быть подсвечены цветными источниками света» ${ }^{19}$.

Вероятно, причина отсутствия в задании конкретного места объяснялась тем, что окончательное решение Моссовета об отводе под кинотеатр участка на южной стороне площади Свердлова, то есть напротив Большого театра, было принято лишь через десять дней после утверждения задания - 10 мая 1936 года²0. В первых числах июня «Архитектурная газета» сообщала о начале проектирования Большого кинотеатра СССР, который «будет построен над вестибюлями станций метро “пл. Свердлова" Революции"» [12]. В заметке особо подчёркивалась сложность этой задачи, которая потребовала проведения ряда совещаний руководителей Отдела проектирования и Отдела планировки Моссовета и проектировщиков с работниками Метростроя. Эскизные проекты, заказанные Д.Н. Чечулину и А.Н. Душкину, должны были быть готовы к 1 августа того же года, однако, этот срок не был соблюдён. Как позднее писал начальник ГУФК Б.3. Шумяцкий, «работа была задержана временным снятием в июне месяце строительства Большого кинотеатра с титулов 221936 г. и внесением СНК СССР (№ 1317 от 21/VII-с.г. ${ }^{23}$ ) изменения в первоначальное задание, снизившего мощность кинотеатра с 4000 мест до 3000 мест» ${ }^{24}$. Таким образом, «к развёртыванию проектирования, начиная со стадии конкурсного проекта, можно было фактически приступить лишь с 20-х чисел июня» ${ }^{25}$.

Несмотря на то, что постановление правительство обязывало ГУКФ «к 1 ноября 1936 года представить в СНК СССР смету строительства большого кинотеатра в Москве» ${ }^{26}$, только в середине октября экспертная комиссия Отдела проектирования Моссовета на выездном заседании в Доме кино рассмотрела конкурсные проекты, которых было уже три. Третий был выполнен коллективом в составе А.П. Великанова, И.В. Ткаченко и Ю.В. Щуко под руководством В.А. Щуко [13] ${ }^{27}$.

Объяснить появление ещё одного проекта авторства ленинградских архитекторов можно, если обратиться к истории реконструкции столицы после принятия постановления ЦК ВКП(б) и СНК «0 генеральном плане реконструкции города Москвы» 1935 года. Согласно этому документу, Моссовет должен был «в течение года, на основе утверждённых красных линий, разработать и утвердить детальные планы застройки улиц и площадей города, оформляемых в течение ближайших

15 Планово-программное задание на составление проектного задания Большого академического кинотеатра СССР на 4000 человек в г. Москве. 1936 г. (РГАЛИ. Ф. 962. 0п. 17. Д. 467. Л. 22).

${ }^{16}$ Там же. Л. 19.

${ }^{17}$ Речь шла об изобретении датского музыканта Томаса Вильфреда, жившего в США, так называемом «цветовом органе».

${ }^{18}$ Планово-программное задание на составление проектного задания Большого академического кинотеатра ССсР на 4000 человек в г. Москве. 1936 г. (РГАЛИ. Ф. 962. 0п. 17. Д. 467. Л. 2).

19 Там же. Л. 22.

20 [Письмо начальника Главного управления кинопромышленности Б.З. Шумяцкого во Всесоюзный комитет по делам искусств при СНК СССР. Декабрь 1936 года] (РГАЛИ. Ф. 962. Оп. 3. Д. 207. Л. 89).

${ }^{21}$ Ныне станция метро «Театральная».

22 Речь идет о списках «титульного» или первоочередного строительства.

${ }^{23}$ Постановление СНК СССР № 1317 «0 титульных списках капитального строительства и плане пуска новых и реконструированных предприятий по кинофотопромышленности и кинофикации на 1936 год» от 21 июля 1936 года (ГА РФ. Р-5446. 0п. 1. Д. 118. Л. 288-297).

24 [Письмо начальника Главного управления кинопромышленности Б.З. Шумяцкого во Всесоюзный комитет по делам искусств при СНК СССР. Декабрь 1936 года] (РГАЛИ. Ф. 962. Оп. 3. Д. 207. Л. 89).

25 Там же.

26 Постановление СНК СССР № 1317 «0 титульных списках капитального строительства и плане пуска новых и реконструированных предприятий по кинофотопромышленности и кинофикации на 1936 год» от 21 июля 1936 года (ГА РФ. Р-5446. 0п. 1. Д. 118. Л. 288-297).

${ }^{27}$ Две публикации об этом событии разняться между собой: в заметке в «Архитектурной газете» сообщается о грядущем рассмотрении проектов 15 октября, и приводится информация, что оно состоится в Доме кино [13]; в заметке в журнале «Строительство Москвы» о прошедшем рассмотрении проектов указана дата 17 октября и нет информации о его месте проведения [14]. 


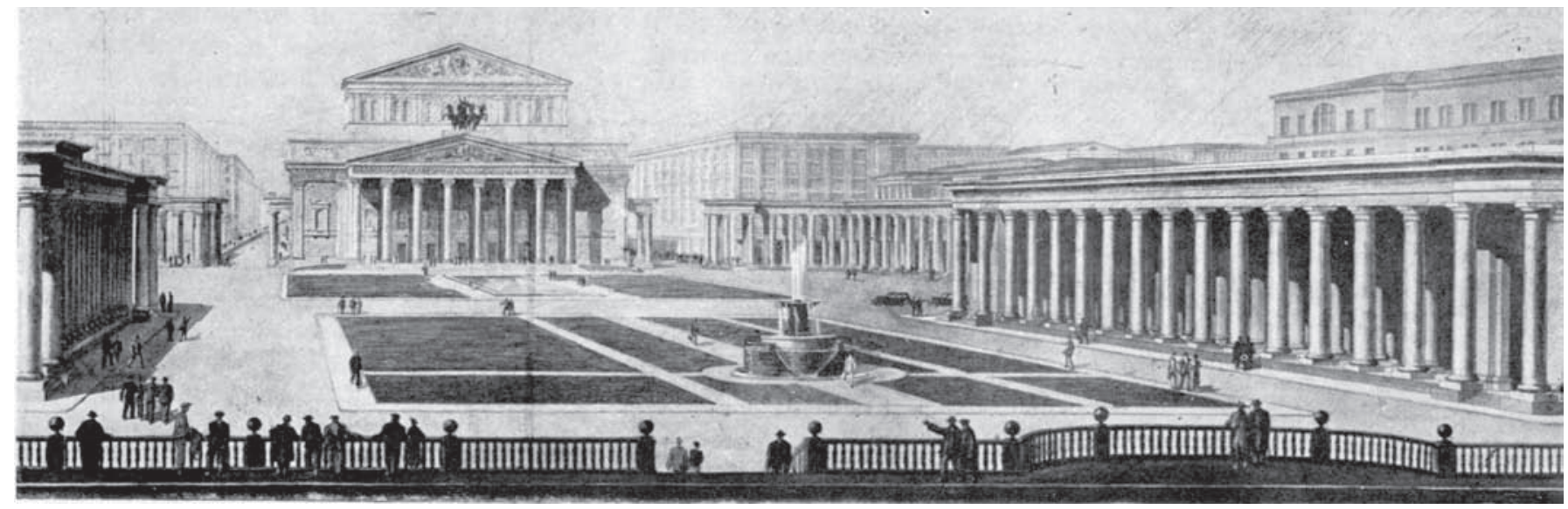

Рис. 3. Проект реконструкции площади Свердлова. Перспектива. Архитекторы И.В. Ткаченко, В.В. Шило. 1936 год (источник: $[17$, c. 5])

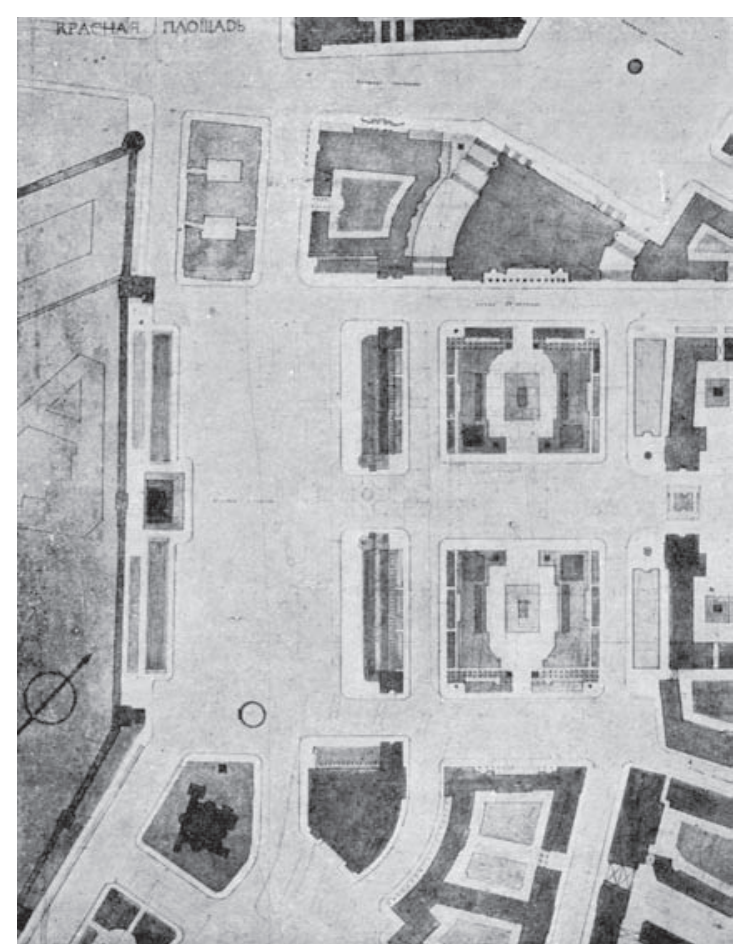

Рис. 4. Проект реконструкции Красной площади. План. Архитекторы Л.А. Ильин, И.В. Ткаченко, В.В. Шило. 1936 год (источник: $[17$, с. 7])

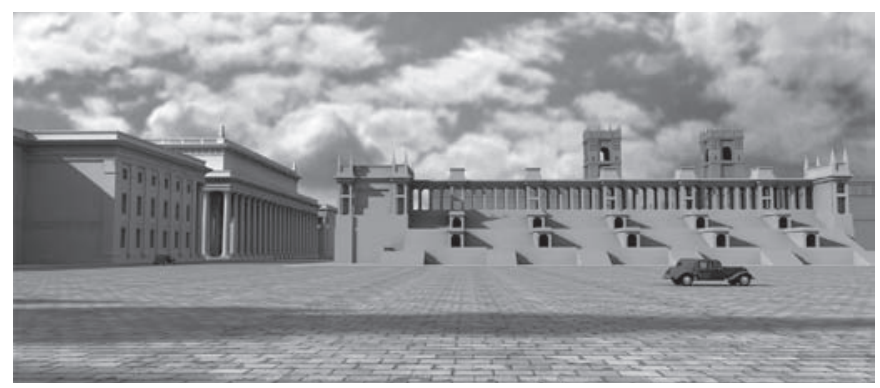

Pис. 5. Конкурсный проект здания Большого академического кинотеатра СССР. Вид со стороны Красной площади. Архитекторы А.П. Великанов, И.В. Ткаченко и Ю.В. Щуко. 1936 год. Трёхмерная модель выполнена Ю.Д. Старостенко в 2006 году десяти лет» [15, с. 4]. В число этих улиц и площадей входили новый проспект, ведущий от площади Дзержинского мимо Дворца Советов в Лужники, и центральные площади Москвы - Ногина, Дзержинского, Свердлова ${ }^{28}$ и Революции. После реорганизации планировочных мастерских Моссовета в середине сентября 1935 года, разработка проекта реконструкции всей этой территории была поручена архитектурно-планировочной мастерской № 2 под руководством В.А. Щуко и Г.Ф. Гельфрейха [16]. Вероятно, именно они пригласили к участию в этой работе главного архитектора Ленинграда Л.А. Ильина и ряд молодых ленинградских архитекторов. Во всяком случае, авторами представленного в середине 1936 года проекта реконструкции центра Москвы числились Л.А. Ильин, И.В. Ткаченко, В.В. Шило, хотя проект и был заявлен как выполненный планировочной мастерской № 2 (рис. 3, 4). Частью этого проекта было здание большого кинотеатра между улицей 25 0ктября ${ }^{29}$ и площадью Свердлова [17, с. 14], и поскольку проект реконструкции центра разрабатывался одновременно с конкурсными проектами здания кинотеатра, привлечение его авторов к конкурсу представляется вполне закономерным. Найденное ими при разработке проекта реконструкции центра Москвы общее планировочное решение здания кинотеатра было использовано в конкурсном проекте. При этом стилистическое решение здания кинотеатра было выдержано в духе их проекта реконструкции площади Свердлова.

Несмотря на то, что проект реконструкции центра Москвы был в целом принят весьма положительно, архитектурное решение здания кинотеатра в конкурсном проекте А.П. Великанова, И.В. Ткаченко и Ю.В. Щуко на заседании экспертной комиссии Отдела проектирования Моссовета не встретило безоговорочного понимания. И.В. Рыльский - референт проекта - в общем высказался о нём одобрительно, «отметив, однако, что архитектура их проекта весьма архаична и скучна»

\footnotetext{
${ }^{28}$ Ныне площади Славянская, Лубянская и Театральная

${ }^{29}$ Ныне Никольская улица.
} 


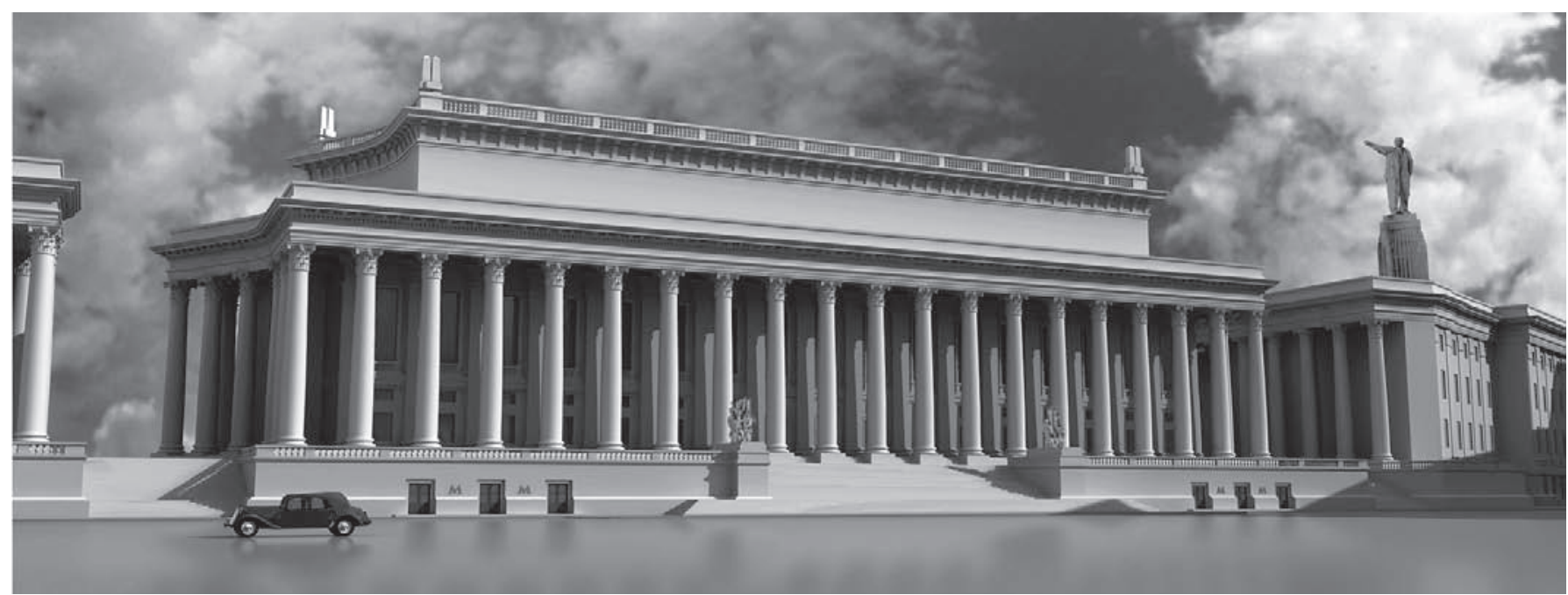

Pис. 6. Конкурсный проект здания Большого академического кинотеатра СССР. Вид со стороны площади Свердлова. Архитекторы А.П. Великанов, И.В. Ткаченко и Ю.В. Щуко. 1936 год. Трёхмерная модель выполнена Ю.Д. Старостенко в 2006 году

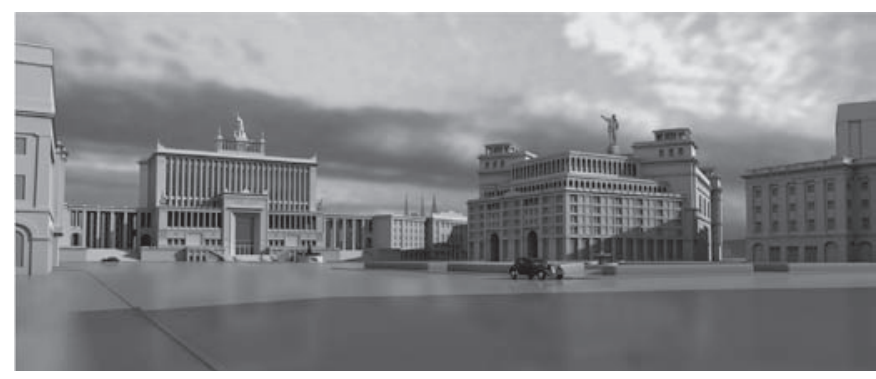

Рис. 7. Конкурсный проект здания Большого академического кинотеатра СССР. Вид от Большого театра. Архитекторы Д.Н. Чечулин и К.К. Орлов. 1936 год. Трёхмерная модель выполнена Ю.Д. Старостенко в 2006 году

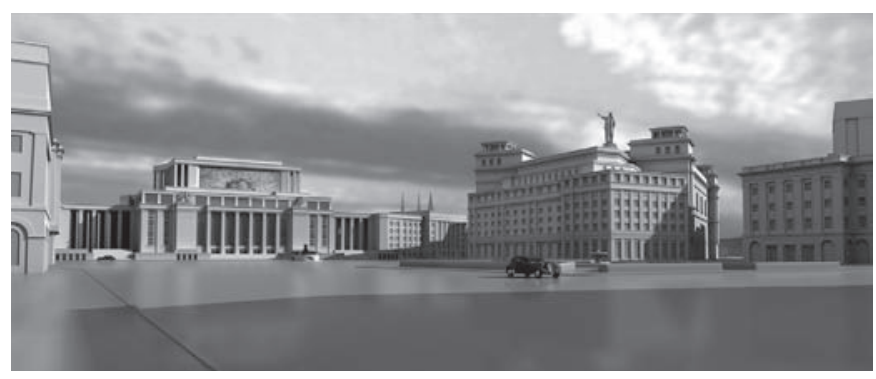

Puс. 9. Конкурсный проект здания Большого академического кинотеатра СССР. Вид от Большого театра. Архитектор А.Н. Душкин (соавторы В.С. Белявский и Н.С. Князев). 1936 год. Трёхмерная модель выполнена Ю.Д. Старостенко в 2006 году.

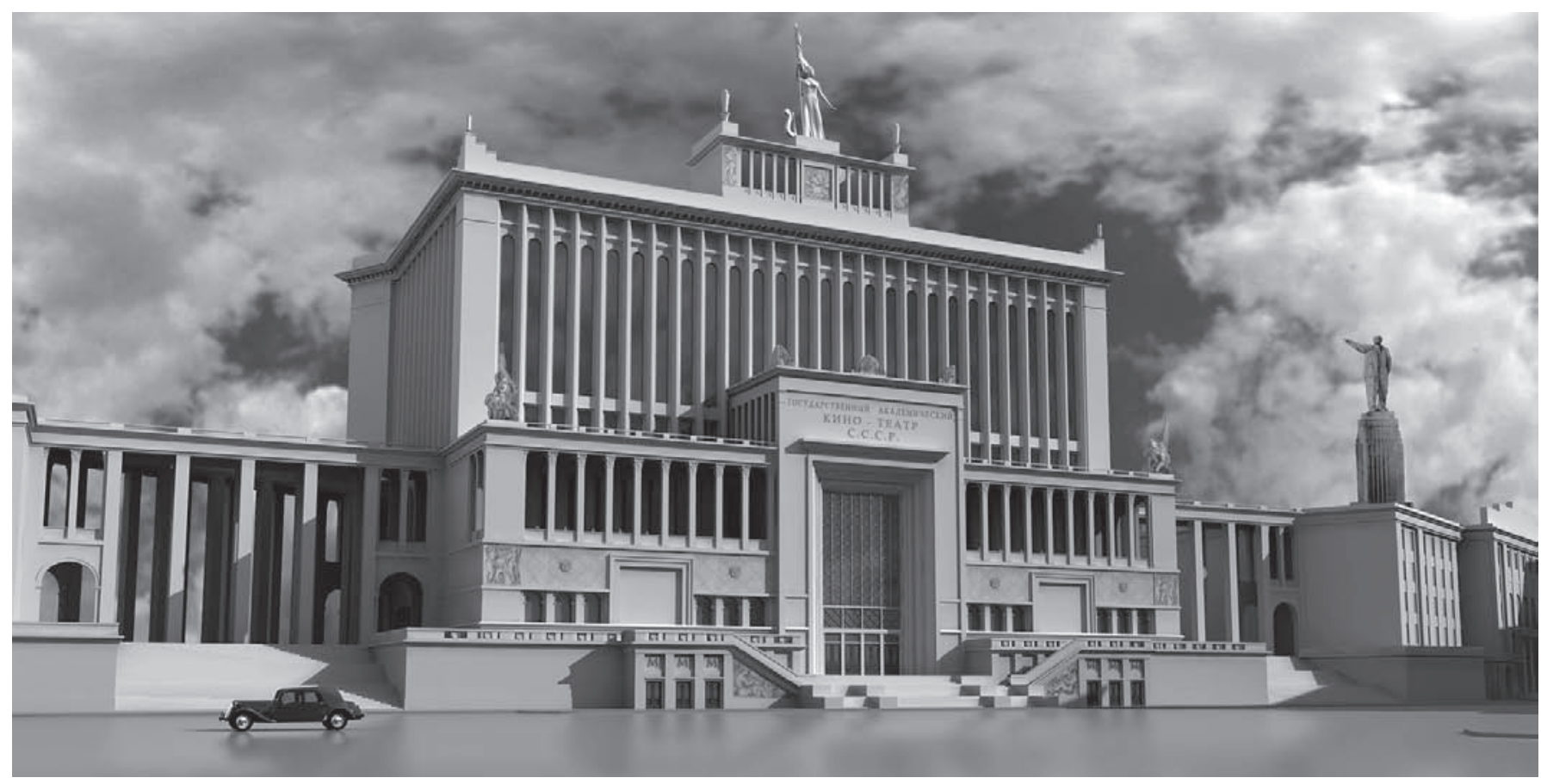

Pис. 8. Конкурсный проект здания Большого академического кинотеатра СССР. Вид со стороны площади Свердлова. Архитекторы Д.Н. Чечулин и К.К. Орлов. 1936 год. Трёхмерная модель выполнена Ю.Д. Старостенко в 2006 году. 
[14] (рис. 5, 6). Работа двух других авторских коллективов также была оценена достаточно критически: «Докладчик по проекту арх. [Д.Н.] Чечулина и [К.К.] Орлова проф. [Н.В.] Докучаев подверг резкой критике проект и высказал мнение, что он не может лечь в основу нового кинотеатра (рис. 7, 8). Тов. [Н.А.] Круглов, выступивший референтом по проекту арх. [А.Н.] Душкина, подчеркнул хорошо решённые автором проекта планы и весьма спорную архитектуру здания» [14] (рис. $9,10)$. Начальник Отдела проектирования Моссовета, подводя итог обсуждению, отметил необходимость дальнейшего обсуждения вопроса, поскольку «ни один из предложенных проектов по своему объёмному решению не может лечь в основу Большого академического кинотеатра СССР» [14].

Появившиеся некоторое время спустя три критические статьи о прошедшем конкурсе свидетельствовали, что ключевая проблема заключалась не только и не столько в архитектурных решениях, предложенных архитекторами, сколько в выборе участка для размещения кинотеатра и требованиях задания на проектирование [18-20]. Желание возвести монументальное здание, по мнению критиков, привело к чрезмерному увеличению объёмов здания, делая его

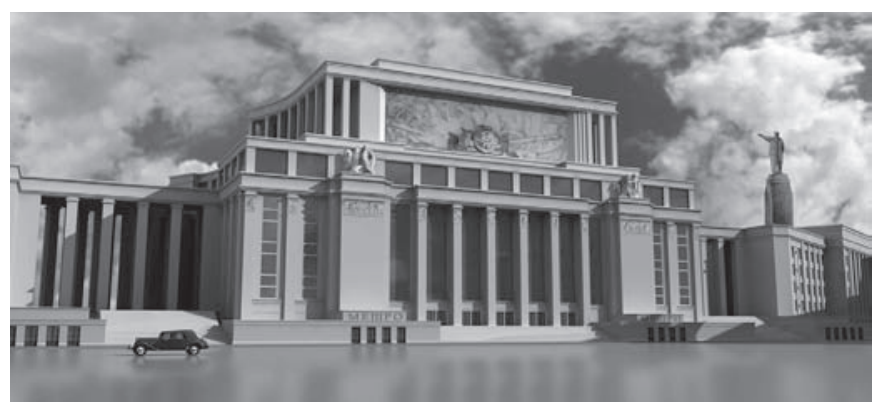

Рис. 10. Конкурсный проект здания Большого академического кинотеатра СССР. Вид со стороны площади Свердлова. Архитектор А.Н. Душкин (соавторы В.С. Белявский и Н.С. Князев). 1936 год. Трёхмерная модель выполнена Ю.Д. Старостенко в 2006 году

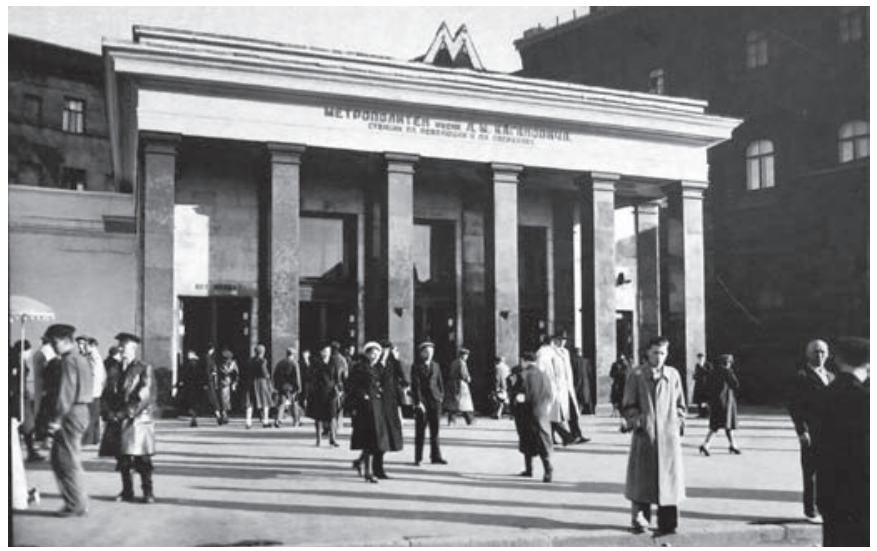

Рис. 11. Наземный вестибюль станций метрополитена «Площадь Революции» и «Площадь Свердлова». Архитектор А.Н. Душкин. 1935-1938 годы. Фото конца 1940-х годов (источник: [2, с. 167]) сооружение экономически нецелесообразным. В то же время, постановка здания напротив Большого театра разрушала ансамбль площади Свердлова, разбивая её на две части. Отсутствие достаточно большого пространства перед столь грандиозным сооружением, каким проектировался кинотеатр (например, в проекте Д.Н. Чечулина высота здания превышала 50 м), должно было исказить его восприятие.

Конкретные архитектурные решения конкурсных проектов вызывали гораздо более широкий диапазон мнений. Несмотря на то, что в двух из трёх статей проект А.П. Великанова, И.В. Ткаченко и Ю.В. Щуко сравнивался с архитектурой европейских музеев или зданий биржи, авторы обзоров сходились на том, что «после безудержного полёта фантазии других авторов, приятно встретить в проекте хотя бы наличие архитектурного такта и отсутствие желания поставить дыбом существующий ансамбль площади с Большим театром» [18, с. 26]. Такая оценка во многом была обусловлена спокойным силуэтом здания без ярко выраженных акцентов. Проект Д.Н. Чечулина и К.К. Орлова Н.В. Докучаев в своей статье называл «гофрированным коробом, плохо связанным с немасштабным порталом и чрезмерными по богатству и разнообразию деталями» [18, с. 23]. А.Я. Карра и Н.Г. Уманский, напротив, считали, что в основе этого проекта лежит правильная мысль «о решении архитектуры кинотеатра в современных формах», хотя и порицали авторов за «излишнюю дробность и большое количество мелких членений», которые «лишают здание монументальности и единства масштаба» [20, с. 3]. Проект Н.А. Душкина и его соавторов критики упрекали в попытке воспроизвести силуэт стоящего напротив театра. Так А.Я. Карра и Н.Г. Уманский полагали, что он «в художественном отношении характеризуется бедностью замысла, подчинённого ампирной схеме Большого театра» [20, с. 3]. Н.В. Докучаев называл здание тяжёлым по пропорциям и писал о грубости деталей [18, с. 26]. Примечательно, что функциональные решения, предложенные в конкурсных проектах, критиками практически не освещались, несмотря на то, что в данном случае они должны были играть едва ли не ведущую роль.

Хотя проекты не получили одобрения архитектурного сообщества, на их основе началось составление проектного задания, завершить которое планировалось к середине декабря 1936 года. В связи с этим ГУК ${ }^{30}$ просил ВКПДИ обратиться в СНК СССР с ходатайством «о предоставлении отсрочки утверждения техпроекта и смет к нему сроком до 15/VI-37 г.» ${ }^{31}$. Необходимость столь значительной отсрочки объяснялась тем обстоятельством, что в здании кинотеатра планировалось устройство вестибюля метро. Это влекло за собой «необходи-

${ }^{30}$ В августе 1936 г. управление фотопромышленностью было передано из ГУКФ в отдельный трест - Союзфото [4, с. 497-498], после чего Главное управление кинофотопромышленности стало Главным управлением кинопромышленности (ГУК).

31 [Письмо начальника Главного управления кинопромышленности Б.3. Шумяцкого во Всесоюзный комитет по делам искусств при СНК СССР. Декабрь 1936 года] (РГАЛИ. Ф. 962. 0п. 3. Д. 207. Л. 89). 
мость увязать фундаменты БАКТа с подземными сооружениями метрополитена». Как сообщал в своем письме Б.3. Шумяцкий, «по заключению нач. Метростроя тов. Роттерта П.П. эта увязка в принимаемом ГУКом варианте планировки БАКТа (3-й архит. проектной мастерской Моссовета) вполне возможна при условии запроектирования специальных конструкций» ${ }^{32}$, но для этого необходимо разрешение СНК СССР. Этот вопрос особо обсуждался на «заседании замов» у председателя ВКПДИ П.М. Керженцева 26 декабря 1936 года. По докладу начальника строительства кинотеатра Иттенбергаз ${ }^{33}$ было принято решение просить правительство об отсрочке предоставления технической документации ${ }^{34}$. После этого в середине января 1937 года переработанное письмо Б.3. Шумяцкого уже за подписью П.М. Керженцева было отправлено в СНК СССР ${ }^{35}$. К нему также прилагался проект соответствующего правительственного постановления, разрешающего также устройство части фундаментов кинотеатра в районе строительства вестибюля метро до утверждения технического проекта ${ }^{36}$. И хотя установить, повлекло ли оно за собой какие-то новые правительственные распоряжения, не удалось, эти документы позволяют утверждать, что к дальнейшей разработке по результатам конкурса был принят проект А.Н. Душкина, работавшего в это время в 3-й проектной мастерской Моссовета.

Это подтверждается письмом начальника Управления капитального строительства ВКПДИ Т.В. Елисеева ${ }^{37}$ от 11 декабря 1936 года, который возражал против такого решения. Он отмечал, что хотя «факт принятия форпроекта Душкина Начальником строительства отрицается, и последний заявляет, что ими не принято по данному вопросу никакого решения», договор с Н.А. Душкиным на детальную разработку технического проекта уже заключён ${ }^{38}$. Т.В. Елисеева не устраивало, что таким образом ВКПДИ лишается возможности выбора проекта из нескольких, что ГУК, не имея утверждённого ВКПДИ форпроекта, «согласовывает его с организациями Моссовета», что строительство планируется вести хозяйственным способом, несмотря на существующий трест Союзкинопромстрой. 0 H также считал излишним приказ Б.3. Шумяцкого от 22 ноября о создании «специальной проектной группы при начальнике Управления строительством» ${ }^{39}$. Как показывает решение, при- нятое на «совещании замов» в конце декабря, доводы Т.В. Елисеева остались без внимания.

Восстановить дальнейшую судьбу проектирования Большого академического кинотеатра СССР на данный момент не удалось. Какие-либо упоминания о нем в документах ВКПДИ после 1936 года отсутствуют. Лишь в отчёте по Госкинопроекту за 1936 год, который сохранился в фонде Министерства кинематографии СССР40, есть сведения о передаче Большого академического кинотеатра «для проектирования в 10-ю мастерскую Моссовета» ${ }^{41}$ без указания точной даты. В итоге вестибюль станций Московского метрополитена «Площадь Революции» и «Площадь Свердлова» (1935-1938), спроектированный А.Н. Душкиным, является единственным воплощённым фрагментом грандиозного проекта (рис. 11).

Среди причин, которые способствовали тому, что проект так и остался на бумаге, можно назвать, в первую очередь, чрезмерную грандиозность и дороговизну замысла. Задержки с проектированием привели к тому, что конкурсные проекты появились уже после постановления ЦК ВКП(б) и СНК СССР «0б улучшении строительного дела» от 11 февраля 1936 г. и по сути вступали в прямое противоречие с положениями этого постановления, призывавшего к типизации, стандартизации и индустриализации строительства. В этом отношении шедшая работа по разработке типовых проектов многозальных кинотеатров небольшой вместимости в гораздо большей степени соответствовала этим требованиям. Кроме того, постановление ЦК ВКП(б) и СНК «О генеральном плане реконструкции гор. Москвы» предписывало построить в Москве в течение десяти лет «50 кинотеатров, в том числе 5 кинотеатров в ближайшие три года» [15, с. 6], поэтому строительство относительно небольших кинотеатров было предпочтительным. Примером попытки следовать новым принципам может служить, например, кинотеатр «Родина» на Семёновской площади (1934-1938, арх. Я.А. Корнфельд, В.П. Калмыков). В этой связи становится понятна первая часть правительственного постановления, принятого в ноябре 1935 года, в котором впервые была озвучена идея строительства Большого академического кинотеатра. Оно предписывало приспособление ряда мо-

32 [Письмо начальника Главного управления кинопромышленности Б.З. Шумяцкого во Всесоюзный комитет по делам искусств при СНК СССР. Декабрь 1936 года] (РГАЛИ. Ф. 962. Оп. 3. Д. 207. Л. 89).

${ }^{33}$ Инициалы установить не удалось.

${ }^{34}$ Протокол № 39 заседания замов. 26.XII.36 г. (РГАЛИ. Ф. 962. Оп. 3. Д. 115. Л. 124).

35 [Письмо председателя Всесоюзного комитета по делам искусств при СНК СССР П.М. Керженцева в СНК СССР. Без даты] (РГАЛИ. Ф. 962.0 О. 3. Д. 207. Л. 91); [Письмо председателя Всесоюзного комитета по делам искусств при СНК СССР П.М. Керженцева в Совет народных комиссаров СССР. 19 января 1937 года] (ГА РФ. Ф. Р-5446. 0п. 20. Д. 2578. Л. 3-4).

${ }^{36}$ [Письмо председателя Всесоюзного комитета по делам искусств при СНК СССР П.М. Керженцева в Совет народных комиссаров СССР. 19 января 1937 года] (ГА РФ. Ф. Р-5446. 0п. 20. Д. 2578. Л. 4). ${ }^{37}$ Инициалы установлены по: [6, с. 36].

38 [Письмо начальника Управления капитального строительства ВКПдИ Т.В. Елисеева заместителю председателя ВКПДИ Я.Э. Чужину. 11/XII-36 г.] (РГАЛИ. Ф. 962. 0п. 3. Д. 207. Л. 93).

${ }^{39}$ Там же. Л. 95-97.

${ }^{40}$ В 1938 году ГУК был выделен из ВКПДИ в отдельный Комитет по делам кинематографии при СНК СССР, который впоследствии был преобразован в министерство.

${ }^{41}$ Годовой отчет «Госкинопроекта». 1936 г. // РГАЛИ. Ф. 2456. Оп. 1. Д. 186. Л. 3. 
сковских зданий под кинотеатры, что и было выполнено. Например, в 1936 году в здании театра бывшего Общества политкаторжан был открыт «Первый кинотеатр» [21, с. 130].

Однако идея устройства кинотеатра на площади Свердлова, как и идея строительства грандиозного здания в южной части этой площади, продолжали периодически напоминать о себе. В 1938 году в гостинице «Москва» проектировался многозальный кинотеатр вместимостью 4000 кресел [22]. И хотя в 1939 году главный архитектор Москвы С.Е. Чернышёв отверг идею строительства какого-либо грандиозного сооружения напротив Большого театра [23, с. 33], в 1960-е годы идея завершения ансамбля площади монументальным зданием возродилась вновь. Этим зданием должен был стать кинотеатр на 6000 мест [24, с. 156], но, как и тремя десятилетиями ранее, проект остался без реализации, а здание Большого театра сохранило роль доминанты Театральной площади.

\section{Лumepamypa}

1. Tyrannei des Schönen. Architektur der Stalin-Zeit / Herausgegeben von Peter Noever; mit Beiträgen von Boris Groys, Vladimir Paperny und Andrej Ikonnikov. - München: Prestel, 1994.

2. Алексей Николаевич Душкин. Архитектура 1930-1950-х годов: архитектурные проекты, документы, живопись, графика: каталог выставки / составитель и научный редактор Н.О. Душкина. - М. : А-Фонд, 2004.

3. Конышева, E.B. Первый двухзальный кинотеатр в Челябинске в контексте формирования образа советского кинотеатра в 1930-е гг. // Academia. Архитектура и строительство. - 2021. - № 1. - С. 40-47.

4. Кино: организация управления и власть, 1917-1938 гг. Документы / составитель, автор предисловия и примечаний А.Л. Евстигнеева. - М. : РОССПЭН, РГАЛИ, 2016.

5. Калмыков, В.П. Архитектура и проектирование кинотеатров / под редакцией Я.А. Корнфельда. - М. : Государственное архитектурное издательство Академии архитектуры СССР, 1941.

6. Вся Москва: адресная и справочная книга. 1936 год. - M., 1936.

7. Архитектура кино. На совещании в Доме архитектора / [Г.] // Архитектурная газета. - 1935. - № 64. - С. 3.

8. 40 лет кинематографа // Советское искусство. - 1935. - № 58 (284). -С. 4.

9. Москва на стройке. Большой академический кинотеатр СССР // Строительство Москвы. - 1935. - № 15. - С. 31-32.

10. Щусев, А.В. Гостиница «Москва» // Строительство Москвы. - 1935. - № 17-18. - С. 3-6.

11. Гостиница «Москва» // Архитектурная газета. - 1935. - № 70. - С. 2.

12. Большой кинотеатр СССР // Архитектурная газета. 1936. - № 31 (104). - С. 4.

13. Хроника // Архитектурная газета. - 1936. - № 57 (129). - C. 4.
14. Москва на стройке. Большой академический кинотеатр СССР // Строительство Москвы. - 1936. - № 20. - С. 31.

15. Постановление ЦК ВКП(б) и СНК СССР «0 генеральном плане реконструкции гор. Москвы» от 10 июля 1935 года // Строительство Москвы. - 1935. - № 7-8. - С. 1-6.

16. На пороге великих реконструктивных работ. Реорганизация архитектурно-планировочного дела в Москве // Архитектурная газета. - 1935. - № 53. - С. 2.

17. Булушев, А.И. Планировка Москвы на новом этапе // Архитектура СССР. - 1936. - № 8. - С. 5-16.

18. Докучаев, Н. Площадь Свердлова и здание Большого кинотеатра СССР // Строительство Москвы. - 1936. - № 2324. - С. 16-28.

19. Корнфельд, Я. Большой академический кинотеатр СССР // Архитектура СССР. - 1936. - № 11. - С. 15-21.

20. Карра, А., Уманский, Н. Проекты кинотеатра на площади Свердлова // Архитектурная газета. - 1936. - № 61 (133). Приложение. - С. 1-4.

21. Федосюк, Ю.А. Москва в кольце Садовых. - М. : Московский рабочий, 1991.

22. На стройках Москвы. Гостиница «Москва» // Строительство Москвы. - 1938. - № 9-10. - С. 56.

23. Чернышев, С. Площади столицы // Архитектура СССР. - 1939. - № 4. - С. 33-35.

24. Бархин, М.Г. Архитектура и город. Проблемы развития советского зодчества. - М. : Наука, 1979.

25. Некрасов, А.И. Гостиница «Москва». В порядке обсуждения нового здания // Архитектура СССР. - 1936. - № 3. - С. 32-35.

\section{References}

1. Tyrannei des Schönen. Architektur der Stalin-Zeit [Tyranny of the Beautiful. Architecture of the Stalin period] / Herausgegeben von Peter Noever; mit Beiträgen von Boris Groys, Vladimir Paperny und Andrei Ikonnikov. München: Prestel, 1994. (In Germ.)

2. Aleksei Nikolaevich Dushkin. Arkhitektura 1930-1950-kh godov: arkhitekturnye proekty, dokumenty, zhivopis', grafika: katalog vystavki [Alexey Nikolaevich Dushkin. Architecture 1930-1950-ies: architectural projects, documents, paintings, drawings: catalogue of the exhibition], N.0. Dushkina (comp., sciense ed.). Moscow, A-Fond Publ., 2004. (In Russ.)

3. Konysheva E.V. Pervyi dvukhzal'nyi kinoteatr v Cheliabinske v kontekste formirovaniia obraza sovetskogo kinoteatra v 1930-e gg. [The first two-hall cinema in Chelyabinsk in the context of the formation of the image of the Soviet cinema in the 1930s.]. In: Academia. Arkhitektura i stroitel'stvo [Academia. Architecture and construction], 2021, no. 1, pp. 40-47. (In Russ., abstr. in Engl.)

4. Kino: organizatsiia upravleniia i vlast', 1917-1938 gg. Dokumenty [Cinema: the organization of management and power, 1917-1938. Documents]. Moscow, ROSSPEN, RGALI, 2016. (In Russ.)

5. Kalmykov V.P. Arkhitektura i proektirovanie kinoteatrov [Architecture and design of cinemas], Ia.A. Kornfel'd (ed.). 
Moscow, State Architectural Publishing House of the USSR Academy of Architecture, 1941. (In Russ.)

6. Vsia Moskva: adresnaia i spravochnaia kniga. 1936 god [All Moscow: address and reference book. 1936]. Moscow, 1936. (In Russ.)

7. Arkhitektura kino. Na soveshchanii v Dome arkhitektora [Architecture of cinema. At a meeting in the Architect's House]. In: Arkhitekturnaia gazeta [Architectural Newspaper], 1935, no. 64, p. 3. (In Russ.)

8. 40 let kinematografa [ 40 years of cinema]. In: Sovetskoe iskusstvo [Soviet art], 1935, no. 68 (284), p. 4. (In Russ.)

9. Moskva na stroike. Bol'shoi akademicheskii kinoteatr SSSR [Moscow at the construction site. The Great Academic Cinema of the USSR]. In: Stroitel'stvo Moskvy [Construction of Moscow], 1935, no. 15, pp. 31-32. (In Russ.)

10. Shchusev A. V. Gostinitsa "Moskva" [Hotel "Moscow"]. In: Stroitel'stvo Moskvy [Construction of Moscow], 1935, no. 17-18, pp. 3-6. (In Russ.)

11. Gostinitsa "Moskva" [Hotel "Moscow"]. In: Arkhitekturnaia gazeta [Architectural Newspaper], 1935, no. 70, p. 2. (In Russ.)

12. Bol'shoi kinoteatr SSSR [The Great Cinema of the USSR]. In: Arkhitekturnaia gazeta [Architectural Newspaper], 1936, no. 31 (104), p. 4. (In Russ.)

13. Khronika [Chronicle]. In: Arkhitekturnaia gazeta [Architectural Newspaper], 1936, no. 57 (129), p. 4. (In Russ.)

14. Moskva na stroike. Bol'shoi akademicheskii kinoteatr SSSR [Moscow at the construction site. The Great Academic Cinema of the USSR]. In: Stroitel'stvo Moskvy [Construction of Moscow], 1936, no. 20, p. 31. (In Russ.)

15. Postanovlenie TsK VKP(b) i SNK SSSR "0 general'nom plane rekonstruktsii gor. Moskvy" ot 10 iiulia 1935 goda [Resolution of the Central Committee of the CPSU(b) and the SNK URSS "On the general plan for the reconstruction of Moscow
City" from July 10, 1935]. In: Stroitel'stvo Moskvy [Construction of Moscow], 1935, no. 7-8, pp. 1-6. (In Russ.)

16. Na poroge velikikh rekonstruktivnykh rabot. Reorganizatsiia arkhitekturno-planirovochnogo dela v Moskve [On the threshold of great reconstructive works. Reorganization of architectural and planning business in Moscow]. In: Arkhitekturnaia gazeta [Architectural Newspaper], 1935, no. 53, p. 2. (In Russ.)

17. Bulushev A.I. Planirovka Moskvy na novom etape [Planning of Moscow at the new stage]. In: Arkhitektura SSSR [Architecture of the USSR], 1936, no. 8, pp. 5-16. (In Russ.)

18. Dokuchaev N. Ploshchad' Sverdlova i zdanie Bol'shogo kinoteatra SSSR [Sverdlov Square and the building of the Great Cinema of the USSR]. In: Stroitel'stvo Moskvy [Construction of Moscow], 1936, no. 23-24, pp. 16-28. (In Russ.).

19. Kornfel'd Ia. Bol'shoi akademicheskii kinoteatr SSSR [The Great Academic Cinema of the USSR]. In: Arkhitektura SSSR [Architecture of the USSR], 1936, no. 11, pp. 15-21. (In Russ.)

20. Karra A., Umanskii N. Proekty kinoteatra na ploshchadi Sverdlova [Projects of the cinema on Sverdlov Square]. In: Arkhitekturnaia gazeta [Architectural Newspaper], 1936, no. 61 (133), Appendix, pp. 1-4. (In Russ.)

21. Fedosiuk Yu. A. Moskva v kol'tse Sadovykh [Moscow in the Garden Ring]. Moscow, Moskovskii rabochii Publ., 1991. (In Russ.)

22. Na stroikakh Moskvy. Gostinitsa "Moskva" [On the construction sites of Moscow. Hotel "Moscow"]. In: Stroitel'stvo Moskvy [Construction of Moscow], 1938, no. 9-10, p. 56. (In Russ.)

23. Chernyshev S. Ploshchadi stolitsy [Squares of the capital]. In: Arkhitektura SSSR [Architecture of the USSR], 1939, no. 4, pp. 33-35. (In Russ.)

24. Barkhin M.G. Arkhitektura i gorod. Problemy razvitiia sovetskogo zodchestva [Architecture and the city. Problems of the development of Soviet architecture. Moscow, Nauka Publ., 1979. (In Russ.)

Старостенко Юлия Дмитриевна (Москва). Кандидат архитектуры. Старший научный сотрудник Научно-исследовательского института теории и истории архитектуры и градостроительства (филиал ФГБУ «ЦНИИП Минстроя России») (111024, Москва, ул. Душинская, 9. НИИтИАГ). Эл.почта: ystarostenko@yandex.ru.

Starostenko Yulia D. (Moscow). Candidate of Architecture. Senior researcher at the Research Institute of Theory and History of Architecture and Urban Planning (9 Dushinskaya st, Moscow, 111024. NIITIAG), branch of the Central Institute for Research and Design of the Ministry of Construction and Housing and Communal Services of the Russian Federation (TsNIIP). E-mail: ystarostenko@yandex.ru. 